\title{
A CRITICISM OF THE HOUSING BILI.
}

\author{
By PETER FYFE, \\ Chief Sanitary Inspector, Glasgou.
}

FOR many years $I$ have been deeply interested in the adequate and F proper lousing of the working classes. The second city of the kingdom has long been striving for an adequate solution of this problem. Nowhere in the country has the administrative mind been more anxiously awaiting light and leading upon it. In these circumstances, I am glad to be afforded an opportunity to discuss the long-expected measure now laid before Parliament by the President of the English Local Government Board.

I will not give a description of the Bill. I assume that the sanitary inspectors of the country have real it, have compared its terms with the Principal Act, and have sought to interpret its meaning by a careful study of the references it continually makes in Part $I$. to various previous enactments. My object is to offer critical remarks upon it, in the hope that not only ourselves, but Members of Parliament who will be asked to agree to its terms (without having the advantage we possess of constant personal touch with the working classes), may see some of the weak points.

The first part of the Bill deals mainly with dishousing and rehousing: the second part with the planning of new townships on fresh sites.

For the dishousing of a too congested population from insanitary dwellings, the starting lever, old and rusty from much disuse and the inroads of time, is that of the 1890 Act. The useless mainspring behind the lever is not to be replaced by something better. Sections 30 and 31 of the Principal Act are not to be repealed. As the lever which controls the steam to a locomotive or other engine is an all-important part of the machinery, so the lever of this dishousing machinery should be, in its composition and connections, of the best material, and direct in its action. By section 30, the lever to be used in starting the dishousing operations is the medical officer of health. It is still to remain his duty to represent to the local authority any dwelling-house which appears to

voL. xxix. No. 11.

$\mathbf{Z Z}$ 
him to be in a state so dangerous or injurious to health as to be unfit for human habitation.

Let us assume that this official, under a vast burden of other work, is fit to undertake such an amount of inspection (for, in solemnly certifying in such language, the work must be personal). In the following section (32) provision is made against his laxity. If the lever for the duty is sufficient (and it ought to be), why should it need the impulse of a mainspring of four or more householders to remind him in writing that they, the complainers, know of dwelling-houses contignous to them, so dangerous or injurious to health that they ought to be closed?

Two practical considerations neerl to be weigled here, in order to estimate the value of this starting machinery. Firstly, I am not aware, in all my experience, of the existence of these "four or more householders." Like other myths, they only exist in some one's imagination, in this case, of those who drafted the Principal Act, not but that there are plenty of people who are ready to complain of what annoys them personally, but they rarely act in combination; and, moreover, they would require, by some means, to gain access to other people's houses in order to ascertain the actual conditions of which they complain. I have known of individuals so complaining, but have not unseldom found they were contiguous proprietors, who were, naturally, secking for a demolition which would improve the amenity of their own property.

Now, in the light of these remarks, let us look at clanse 13 (1) of the Bill. It re-enacts, with certain amendments, section 32 of the Act of 1890. Here it is declared to be the duty of the local authority to see that their medical ufficer of health does his duty, and on his representation, or that of any officer in their service, or on information given by any other person that dwelling-houses are unfit for human habitation, they may take certain action.

The idea working in the mind of the draughtsman both of the old section 32 and of the new clause 13 (1) is difficult to understand. The words "or of any ofjucer of the anthority" introduce another lever for the purpose of starting the legal machinery. This other lever has no name. It may be a policeman, a road surveyor, a lighting or water inspector, or a sanitary inspector. Each of them seems to have the power to suggest the need for action to a local authority. The local authority may, however, safely ignore any representation from such. It is only when complaints originate with four or more contiguons householders that the authority may be compelled to move, through the representation of the medical 
officer of health, and then only by this quadruple-householder mainspring pressing upon the Local Guvernment Board for an inquiry, if they elect to do nothing. Thus four householders have more compelling power than any medical officer of health, so far as making their complaints effective is concerned, and their complaints are made of greater consequence than the representations of any officer of the local authority.

I have shown that it is very unlikely that the "four houscholders" will ever trouble themselves in the business, notwithstanding the powers placed in their hands; nor will that nebulous entity "any officer" think it worth while to make a representation which may promptly be relegated to the local authority's wastepaper basket. Thus, in practice, the Bill, if passed as it stands, will result in one official performing the inspecting and representing part of the work; and, even then, the local autlority may, if they sce fit, disregard his representation, unless he can command the services of the aforesild complaining householders. It is a lexutiful example of an enactment providing the means of how not to do it, or of cluing it very leisurely, if a local authority be so mindel.

Complaint has, again and again, been made throughout the countr". as to the number of local authorities who have done little or nothing under the Honsing Acts, and yet, when a chance occurs to improve the machinery and to put the levers and springs of action into effective working order, the old, inefficient procedure is once more to be anlopterl.

Perhaps no body of trained men are so intimately acquainted with the terrible conditions amid which the labouring classes continue to dwell as the sanitary inspectors of the country (going continually in and out amomg this class of the population, knowing and seeing every insanitary detail, the damp walls, the rotten woodwork, the decaying amd broken plaster, the leaking roofs, the want of rentilition and light, and the miry and filth-sodden surroundings), and yet these, the statutory officers under the Public Health Acts for the discovery and removal of nuisaluces, are not once alluded to in the Bill. They have no statutory duty to report to their authorities upon dwellings unfit for habitation. It may be presumed they are classed under the words "any ufficer"; but it is an old and true saying that everybody's business is nobody's business.

Local authorities anxious to do their work and face their responsibilities make use, I know, of their sanitary officers in the detection of dwellings unfit for human habitation. I have been utilised in this way many times, and donbtless many of the officers I am addressing have done much valuable work in this direction. Without their reports and repre- 
sentations on this subject, the housing of the people would be a great deal worse than it is at the present time.

Supine local authorities, on the other hand, have ground for excuse if they elect to let the law take its inexpeditious course, and await the inspection and formal certificate of their medical officer of health; as what is the statutory duty of an otherwise very busy official, and only his, cannot be considered by the legislature to be one of very great importance or urgencr.

I claim that it shonld be the statutory duty of the sanitary inspector as well as that of the medical officer of health to report to the local authority upon any uninhabitable houses in his district; nay, I go further, and aver that any Minister of State who was sincerely anxious to clear the country of the wretched hovels in which too many of its poorer inhabitants are dwelling, would not neglect the present opportunity to utilise to the full the services of those, than whom none are more intimately acquainted with the circumstances and necessities of the case.

But I have another serious objection to this clause as it stands. A certificate that a house is in such a state as to be "dangerous or injurious to health" is behind the times. Nuisances at one time had so to be certified before legal action could be taken to abate them: to-day both statute and common-sense declare that an ordinary sanitary nuisance need not be proved "dangerous or injurious to health" to be summarily put down. There are many houses unfit for human habitation, in the modern sense, regarding which, to swear they were "dangerous or injurious to health" would be impossible to any man with an unstretchable conscience. Again and again we have lost cases in Glasgow through medical gentlemen going into the box and conscientiously swearing that rotten-looking dwelling-houses were neither dangerous nor injurious to the health of the tenants. We do not know much of the health of our forefathers, the Troglodytes, nor of our contemporaries, the Lapps; but in the caves of the former, as in the snow-huts and wooden "njallas" of the latter, those people appear to have been able to rear up a hardy and surviving race.

Clause 27 of the Bill itself forms a curious commentary upon the antiquated and dangerous verbiage of clause 13 . It lays upon all landlords who contract to let houses for habitation by persons of the working classes, the responsibility of seeing that their houses, during the holding by the tenants, shall be kept " in all respects reasonably fit for human habitation." 
Now, the landlord's responsibility under clause 27 only extends, for Scotland, to houses rented at $\mathfrak{f} 8$ per annum, or about 3s. 1 d. per week. All workmen's dwellings above that small rental are outside the clanse. The working men of the country will be able to understand from this how the Bill will help them. As a matter of fact, the clause will be of no use but to a limited number, and those the verr poorest, who cannot afford to pay more for their dwelling than the sum I have named, as that is the class of house which is defined and specified in clause 26. To make the Bill a really effective one for our working classes, as against a careless and indifferent landlord, the rental qualification should be raised to not less than $£ 24$ a year, or 9 s. 2 d. a week, which is a common rent for dwellings for the working classes of this country.

Coming back to clause 19, let us try to see the difference between a house so "dangerous or injurious to health as to be unfit for human occupation," and a house not "in all respects fit for human occupation." You will notice the difficulty of proving the former statement. It is only in cases of extreme dilapidation, dampness, and disrepair that a certificate could be issued against any house, which could not be met by a counter medical certificite that the house was not dangerous or injurious to health.

There are houses standing and occupied to-day in Glasgow, and I doubt not in every large town in the Kingdom, which have been so certified by the medical officer of health, and which are a reproach to the community, but which cannot be closed because of the words I complain of in this clause. The case would be different if we had only to prove they were "not in all respects fit for human occupation."

Talke the house rotten, blistered, and cracked in the plaster, so that proper cleansing of the walls and ceilings is impossible; and the flooring boards so worn and gaping in the joints that the floor cannot be washed withont the water soaking down into the deafening beneath. There are hundreds of these in every town, which ought to be closed by order until the owners renewed plaster and flooring. They have little else wrong with them, and many of them, under the care of poor but cleanlydisposed tenants (who often put paper over the rotten plaster), look fair in appearance to the superficial observer. They, under a degraded tenancy, would quickly become " clangerous or injurious to health," but the clean tenant saves a certifiable house from certification: it might easily become, hut is not presently, in her keeping, a honse "dangerons and injurious to health." I have seen such houses so full of cracks and fissures that vermin, in warm weather, find nesting-places which would 
defy the most strenuous efforts (short of stripping the whole plaster) to eradicate them.

A true Housing Bill should be an instrument in the hands of local authorities which would enable them to bring working men's dwellinglouses up to a reasomable occupation standard without the need to ask a medical officer of health to stretch his conscience to such an extreme point as clause 13 makes him do. To do this is, and has been, to court defeat; and in Scotlind this will continue, as the case against the house has to be proved before a sheriff. In England, the Local Government Board may cast proof orerboard, and take the eridence of its own inspectors in every disputed case; but this also is a dangerous path to tread. It puts a power to close property, independently of proof as to whether it is injurious to health, into the hands of the Board, which in due time will bringr its own Nemesis.

Properly enough, the owner is, after being serred by the local authority with a closing Order, entitled to put his house into a habitable condition, or he may appeal to the Lucal Government Board if in England, ind to the sheriff if in Scotland, against the Order. The clause does not make it clear whether the Order to close is to take effect prior to the result of the appeal; if not, then past experience shews that during the interregnum between the date of the Order and the final decision of the Board, the tenants will have to suffer all the inconvenience incidental to tradesmen working in the houses, in order to get them ready for the official inspection. This is sometimes very great, and, when wet plaster-work forms part of the repair, must lave injurious effects on the inmites, and especially on the children.

In every case where the repairs required are extensive the tenants should he temporarily removed, and the compensation paid to them which is referred to in sub-clause (4) of clause 13.

I now pass to clause 15 , dealiny with "charging orders." It refers one back to section $3 i$ of the Principal Act. It looks quite in order that any owner who has been at considerable outlay of capital to put his property into a thoroughly habitable state should be able to get from the local authority a "charging order," or, in other words, a certificate that he has, as matter of fact, spent a certain amount of money in repairing it; but in view of the great diversity of both legal and lay opinion as to the policy of a local authority giving an owner any information in detail, either as to what is complained of in respect of his property, or as to what he must do to make it, in their opinion, habitable, the clatuse leaves the whole subject in obscurity. 
When is such a "charging order" exigible? When we turn to section $3 b^{\circ}$ of the Principal $A c t$ we find these words in sub-section (1):-

"When any owner has completed, in respect of any dwelling-house, any works required to be executed $b_{\text {!y }}$ an order of a local authority under this part of this Act, he may apply to the local authority for a charging order."

This seems to pre-suppose that, in issuing their Closing Order, the local authority shall, unless they think the property cannot be made habitable by repairing, require certain works to be executecl. There are, however, no words in the Bill making this compulsory on local authorities, consequently they do not consider they ought to specify anything with regard to the property, nor make any requirement upon the owner, but simply to close it. If this is the intention of the legislature they should not leare it ambiguous, as in the Bill in clauses 13 and 14, and then in clause 15 by reference to section 36 of the Act, making a charging order forthcoming upon the supposition that local authorities will do something, which they will not do unless under statutory requirement.

It is not yuite an honest policy. A man might spend $£ 500$ upon his property rather than lave it closed, but, unless it was spent in terms of section 36 of the Principal Act (i.e., on "works required to be execnted by an order of a local authority") he would nut be entitled to receive any charging order.

With regard to clause 17 , a question arises as to whether the restriction it puts upon the power of courts of summary jurisliction in certain cases to extend the time allowed for the execution of repairs upon a building or for its demolition, will apply to Scotland notwithstanding sub-clause (13) of clause 44, which substitutes the sheriff for the Local Government Board. If it only applies in England I have nothing further to say; but as the sheriff court in Scotland, in which such appeals will be heard, is a court of summary jurisdiction, it seems to me Scotland should be specially exempted from the operation of this clause.

Clause 20 will raise some complicated questions. It is an amendment of an amendment upon the procedure necessary upon a local authority decidinur to go in for an improvement or reconstruction scheme requiring a compulsory purchase of land. It proposes to cut away sub-sections $(a)$ and $(b)$ of section 5 of the Act of 1903 , which itself is an amendment of section 1 (sub-section 4) of the Principal Act. It appears to mean that, when the Local Government Board have once issued an order sanctioning a reconstruction scheme under Part I., section 8 , or under section 39 of Part II., and has authorised the compulsory purchise of land or buildings for the scheme, a local authority need not be hampered by all the circum- 
locutory processes required by the above-recited sections, under which it liad to go to Parliament for confirmation of the scheme.

The clause, however, does not appear to affect sub-sections (4), (5), (6), and (7) of section 38 of the Principal Act, which deal with the compulsory purchase of land or building sites under the Lancls Clauses Acts. Now, it will be noticed that sub-section (5) of section 32 of the Principal Act, dealing with obstructive buildings (which is not to be repealed), provides :-

"The owner of the lands may, within one month after notice to purchase the same is served upon lim, declitre that he desires to retain the site of the obstruetive building. and undertaks either to pull down or to permit the local authority to pull down the obstructive building. and in such case the owner shall retain the site and shall receive compensation from the local authority for the pulling down of the obstructive building."

As, under the succeeding section, the local authority may, through an order of the Local Govermment Board, acquire this site by compulsory purchase under the Lands Clauses Acts, a local authority has two inquiries to face, in the event of a proprietor desiring to retain a site he cannot adequately utilise, and which may be compulsorily taken from him. It means (in Scotland, at any rate) first, a fight before the sheriff, before the obstructive building is removed, and, if the proprietor or proprietors choose, another fight later on, on the question of the value of a site to be compulsorily purchased, regarding which the proprietor or proprietors have averred their wish to retain it for their own purposes.

Perhaps nothing las delayed the removal of obstructive buildings in large cities so much as this power of pre-emption which owners can exercise with regard to the sites of obstructive buildings. If this were taken away, and a local authority could at one and the same time remove objectionable buildings and acquire the sites on which they stand, without being put to the expense of a double inquiry, a great advantage would be gained. Section 20 simplifies one part, but leares the complication and expense incidental to section $38(5)$ as they were.

Clause 21 should have a rider attached to it, to the effect that it would only be the duty of the local authority to exercise the power griven in Part I. of the Principal Act where it was proved to be necessary, and when they had not, under a private Bill or Provisional Order, obtained somewhat similar powers. They should be left at liberty, as formerly, to apply for an improvement measure of their own, in lieu of adopting the powers given in the General Acts.

I have no doubt that many local authorities in the country will express 
serious objections to clause 23 . It gives the Local Government Board a roving commission to send an officer or inspector where they choose, to make an inspection or hold an inquiry. No complaint by twelve or four householders or any others is necessary. The arbitrary ipse dixit of the Board is all that is needful to put any local authority on its trial, and whether convicted of a lapse of duty or not, they must bear all the expense of the inquiry. I anticipate, when the Bill comes before the House, considerable amendment will be made upon this clause.

I have already, in referring to clause 13 , had something to say on clause 27. It puzzles the simple Scotch mind. The word "landlord" is defined as a person who lets a working-man a dwelling-louse "under any contract." As distinguisher from this person there is the "ouner," who, in English parlance, is called "the owner for the time being" or the "rack-renter," as defined in the Public Health Act, 1875. If the landlord chooses not to make a formal contract in the matter I presume the clause will not apply. To the Scotcl mind it looks a curious picce of legal machinery. In my view it ought not to matter in the slightest whether houses built for habitation by the working classes were built and let under a specific contract or not. It should be sufficient that the working classes inhabit them from year to year, in which case, contract or no contract, the dwellings should be presumed to be "reasonably fit for human habitation." If they are not so, and not made so as expeditiously as may be by the owners thereof (whether these be landlords or not), the local authority should be entitled to step in without being required to prove under clause 13 that the dwellings are in such a state as to be "dangerous or injurious to health." In any case, the low rental specified in clause 26 (before referred to) makes the benefits to be derived from the clauses delusive; and, in view of the higher rents charged for workmen's dwellings of two or three apartments, places the clanse in the categry of those pretentions but inadequate efforts to amelionate the housing conditions of our working classes above the lowest.

In clause 34 it is proposed that Parliament shall grant to the Local Government Board power to compel any two or more local authorities to act jointly for any purpose of the Ilousing Acts, either generally or in any special case. It was probably foreseen by the Presilent of the Local Government Board that, unless assurance could be had that the area to be dealt with in comnection with a town-plamning schene would, when the scheme was finaly completed, fail to be administered and supervised in all respects by the principal undertaking local authority, little or nothing 
would be done. Manifestly, no urban local authority would willinglyinterest itself financially or otherwise in such a scheme unless on the distinct understanding that the citizens of the new area are to be de facto its own citizens. I see nothing in the Bill providing for this.

Any city or town that might undertake town-planning or suburbplanning in respect of an extensive area on its borders, but under county administration, for all the Bill provides, may find, after its work was concluded, that it had to face a fierce parliamentary opposition before Committees of both Honses for the acquisition of the new territory; consequently the Board are, in this clanse, to be empowered, if they think it expedient, to compel the burgh and county to joint action. This compulsitor by the Board is to have the same weight as a Provisional Order obtained under section 279 of the Public Health Act of 1875 for the formation of a united district; but, unlike the Act, the Bill does not contain an excepting clause such as is provided in section 286 for urban districts. This section of the Public Health Act exempts burghs containing a population of twenty-five thousand and upwards, which are not to be included in any union-of-district scheme without their consent.

It hardly needs argument to prove that it is on the margin of large and congested cities that housing or town-planning schemes are most required, or that it is the working classes in such centres that are in most. urgent want of good housing. fresh air, and abundant sunlight; nor need I occupy time showing that such large inclustrial populations can most. economically and effectually proville the water-supplies, sewerage, scarenging, and lighting so essential for a fresh communal life. Now, they are not going to plan out any fresly urban area in their vicinity, and supply its inhabitants with these timgs, except uncler a statutory guarantee that the township (composed probably, for most part, of their own citizens) is to be part and parcel of the city.

An amendment, therefore, of clauses 34 and $40^{\circ}(3)$ is necessary, in the interests of all large towns. They must either be specially exempted, as in section 286 of the Public Health Act, or a clause should be inserted in the Bill placing the newly accuired land to be built upon, if not within the municipal area, under their jurisdiction and administration.

Probably the county authorities will object to this, and will desire, when all is completel, $t$ o be left in a position to oppose to their utmost annexation of the new valuable area. The President of the Board will have to choose his course. The antagonism is there, and it will not be minimised by any proposals for enforced action such as is laid down in clause 34 . No one can deny that cities must continue to expand, 
and it is equally certain that this expansion ought to proceer on the main lines of Part II. of this Bill, but the Bill itself ought clearly to set forth with whom the responsiblity of administration is to rest, if the acquired area is coterminous with the existing boundaries of the town. A joint administration in such a case is unthinkable.

Not a few cities are already severely hampered in their natural growth by the accumulation rouml them of small communities, each working out its communal salvation upon lines of least financial resistance, either independently or as county units. This, of course, means the minimum of burghal machinery consistent with a fair amount of comfort and convenience. Any system which would add to these, whether independently or jointly administered, could not expect the support of the cities and large towns of the Kingdom.

These criticisms upon Part $I$. of the Bill have left me no time in which to review Part II., dealing with town-planning as such. A great deal might be said upon this portion of the measure, both appreciative and adversely critical; but. I must defer any further remarks upon it.

From what I have stated, rou will have gathered my- opinion upon three important points in this important measure:-

Firstly, that the Bill is unjust to the great and influential body of public servants known throughout the kingdom as Sanitary Inspectors, who do so much laborious duty daily in connection with the very work it is intended to promote;

Secondly, that the working classes, above the very poorest class, who pay the humble 3s. 1l. per week or thereby, will not have the advantige they might reasonaly claim from such a measure (that is, the assurance that the landlords or owners of their houses shall le bound to maintain them in all respects in a state fit for habitation); ind

Thirdly, that local authorities, particularly in England, are placed by the Bill at the merey of the Local Gorernment Board and their inspecting officers, without any opportunity to appeal agaiust their decisions. 